\title{
Annual Water Status, Development, and Flowering Patterns for Rosmarinus officinalis Plants Under Different Irrigation Conditions
}

\author{
Emilio Nicolás ${ }^{1}$ \\ Departamento de Riego, Centro de Edafología y Biología Aplicada del \\ Segura, CSIC, Apdo. 164, E-30100, Espinardo (Murcia), Spain; and Unidad \\ Asociada al CSIC de Horticultura Sostenible en Zonas Aridas (UPCT- \\ CEBAS), Paseo Alfonso XIII, s/n. E-30203 Cartagena (Murcia), Spain \\ Trinitario Ferrandez and José Salvador Rubio \\ Departamento de Riego, Centro de Edafología y Biología Aplicada del \\ Segura, CSIC, Apdo. 164, E-30100, Espinardo (Murcia), Spain
}

Juan José Alarcón and Ma Jesús Sánchez-Blanco

Departamento de Riego, Centro de Edafología y Biología Aplicada del Segura, CSIC, Apdo. 164, E-30100, Espinardo (Murcia), Spain; and Unidad Asociada al CSIC de Horticultura Sostenible en Zonas Aridas (UPCTCEBAS), Paseo Alfonso XIII, s/n. E-30203 Cartagena (Murcia), Spain

Additional index words. ornamental plants, deficit irrigation, water relations, gardening, growth, flowering

\begin{abstract}
The annual water status and phenological patterns of Rosmarinus officinalis plants in relation to irrigation were studied to improve the use of this species in gardening conditions. Rosmarinus officinalis seedlings were pot-grown for 4 months in the nursery. After this period, plants were transplanted to field conditions before three irrigation treatments were applied from Nov. 2000 to Dec. 2001 (control and deficit treatments: C, T-1 and T-2, respectively). The total amount of water applied by irrigation during the experimental period was $167 \mathrm{~mm}$ for control, $83.5 \mathrm{~mm}$ for T1 (50\% of the control), and $50 \mathrm{~mm}$ for T-2 (30\% to the control). Two main periods of vegetative growth (beginning of spring and fall) were observed in all treatments. At the end of the experimental period, deficit irrigation had altered the morphology of the $R$. officinalis plants, reducing plant height and shoot growth. Maximum flowering intensity occurred at the beginning of fall for all irrigation treatments. Deficit irrigation treatments induced a more intense flowering density, although of lower longevity than control plants. The annual pattern of shoot water potential at predawn reflected the irrigation regimes, although less difference resulting from irrigation effect was detected in this parameter at midday. Plants under deficit irrigation showed a conservative strategy in the use of water, reducing stomatal conductance. This finding may be of use for the successful gardening of Rosmarinus officinalis plants in semiarid conditions.
\end{abstract}

During recent years, research into new ornamental species has increased in parallel with the demand for native plants. This follows the increasing sensitivity of consumers toward the environment, which has resulted in an increase in the use of these species in xerogardening, landscaping, and

\footnotetext{
Received for publication 30 Jan. 2008. Accepted for publication 15 May 2008.

This research was supported by CICYT (AGL200505588-C02-1-2), CDTI (IDI-20070868), and Fundación Séneca (05660/PI/07) projects.

We thank the local municipal council from Murcia (Spain) for its assistance.

${ }^{1}$ To whom reprint requests should be addressed; e-mailemilio@cebas.csic.es
}

restoration activities (Franco et al., 2006; Savé et al., 1999).

In the Mediterranean area, the scarcity of rainfall and the high evaporative demand of the atmosphere mean that the maintenance of mesic landscapes requires a substantial but rationalized amount of irrigation (AraújoAlves et al., 2000). Also, the efficient use of water in urban gardens contributes substantially to the conservation of this resource. Therefore, in the last years, there has been increased interest in plants that have low water requirements. In this sense, the use of native species of wild flora may be an interesting practice because they usually are not water-wasters and their growth patterns are very well adapted to the Mediterranean environmental conditions (Morales et al., 1998; Savé et al., 1993). Although it is known that ornamental species differ in form and respond to water stress in different ways (Ludlow, 1989), little information about the water use of these species is found in the literature.

The use of wild Mediterranean plant species, including Rosmarinus officinalis, has increased and may be an interesting solution because of their good resistance to adverse environmental conditions (Clary et al., 2004; Franco et al., 2000; SánchezBlanco et al., 1998, 2004a, 2004b; Savé et al., 1993). Although studies in relation to cultivation techniques in $R$. officinalis have been realized (Silva and Pedras, 1999), the agronomic and physiological responses to irrigation are scarce.

The purpose of this study was to evaluate the effect of different irrigation treatments on the response of Rosmarinus officinalis plants to maintain its ornamental value for use in Mediterranean gardening conditions. For that, changes in growth, water relations, and flowering characteristics were determined.

\section{Materials and Methods}

Plant material and experimental site. Rosmarinus officinalis L. (native of the province of Murcia, southeast Spain) seedlings were used. The most homogeneous selection of seedlings possible (10 to $12 \mathrm{~cm}$ in height) was made avoiding, to the greatest extent possible, variations resulting from sexual production. The plants were grown in $1863-\mathrm{cm}^{3}$ plastic pots filled with a substrate of black peat, perlite, and a clay loam soil (1:1:2 by volume) for 4 months in nursery conditions (Mar. 2000 to July 2000). On 28 July, 54 plants were transplanted to an experimental site belonging to the local municipal council in Murcia (southeast Spain) and distributed in three plots per treatment (six plants/plot). Plant spacing was a $2 \times 1.5-\mathrm{m}$ square pattern. The soil has a clay loam texture with a $2.12 \%$ organic matter content. These plants were maintained in the field and well-irrigated conditions to achieve their adaptation to natural conditions until the experiment was started (Nov. 2000 until Dec. 2001).

The climate of the area is typical Mediterranean conditions with mild winters, low rainfall, and very hot, dry summers. During the experimental period, the mean minimum and maximum temperatures were 6.3 and $30{ }^{\circ} \mathrm{C}$, respectively (Fig. 1A). Thus, the minimum temperature were registered in Feb. 2001 $\left(2{ }^{\circ} \mathrm{C}\right)$ and maximum temperature in Aug. $2001\left(41^{\circ} \mathrm{C}\right)$. Global radiation and vapor pressure deficit averaged values varied from 100 and 0.5 (winter) to $300 \mathrm{~W} \cdot \mathrm{m}^{-2}$ and $2 \mathrm{kPa}$ (summer), respectively (Fig. 1B). In the last 4 months of measurements (Sept. to Dec. 2001), rainfall was $\approx 80 \%$ of the total rain during the entire experimental period $(298.4 \mathrm{~mm})$.

Irrigation management. From 28 July until 1 Nov. 2000, all plants were irrigated daily to maintain the soil around field capacity with an automated drip irrigation system. Thus, the irrigation was controlled automatically by a head unit programmer, which 


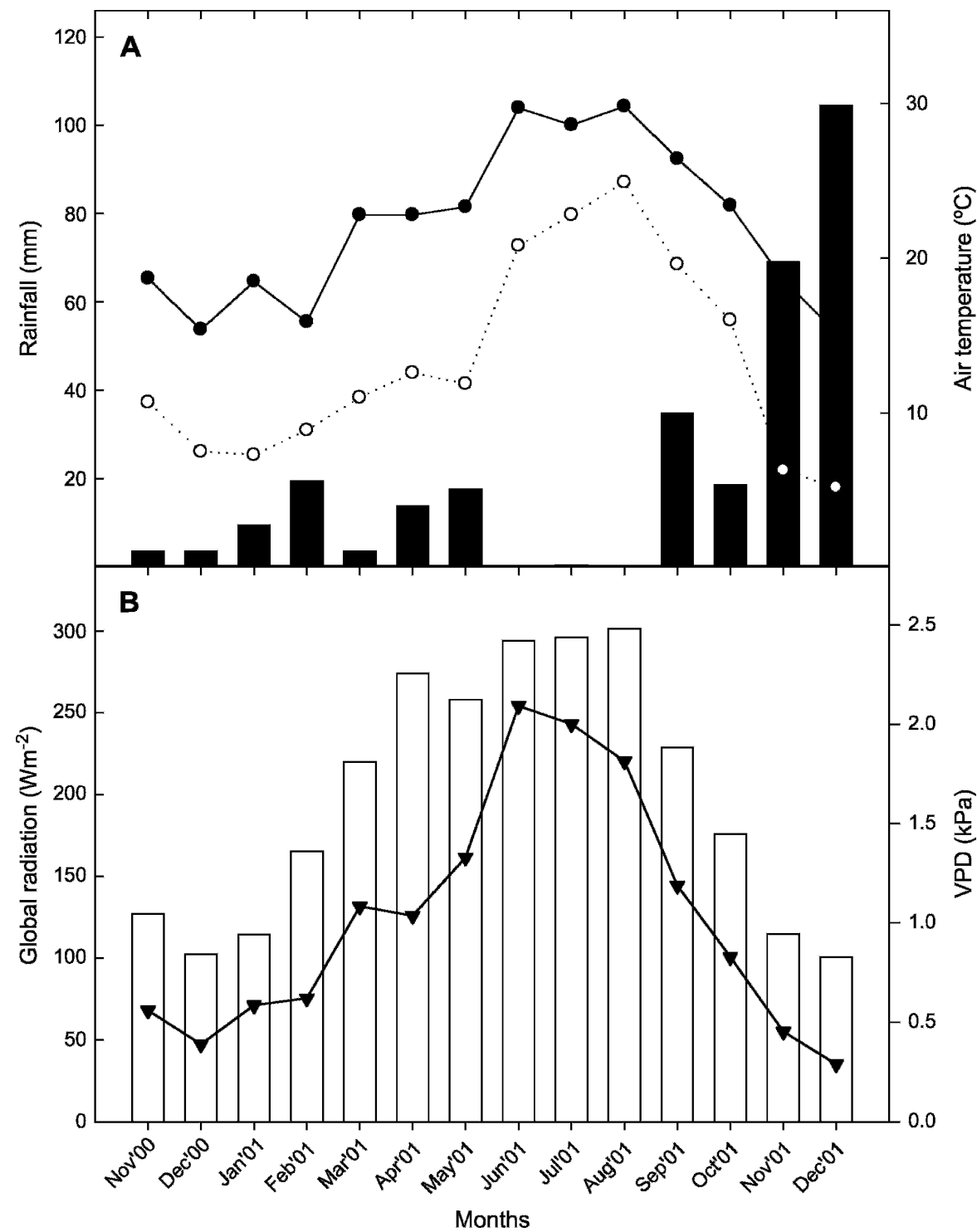

Fig. 1. Meteorological conditions along the experimental period. (A) Monthly rainfall (mm, black histograms) and mean maximum (solid line) and minimum (dotted line) air temperature $\left({ }^{\circ} \mathrm{C}\right)$. (B) Mean averaged vapor pressure deficit [(VPD) $\mathrm{kPa}$, solid line] and global radiation $\left(\mathrm{W} \cdot \mathrm{m}^{-2}\right.$, white histograms).

maintained the soil-matric potential at $\approx-30$ $\mathrm{kPa}$ (monitored with tensiometers placed at $30 \mathrm{~cm}$ depth).

Afterward, from Nov. 2000 to Dec. 2001, three irrigation treatments were applied in a completely randomized design with three plots (18 plants) per treatment: control (C), with soil matric potential $\left(\Psi_{\mathrm{m}}\right)$ at $\approx-30 \mathrm{kPa}$, and two deficit irrigation (T-1 and T-2), corresponding to $\approx 50 \%\left(\Psi_{\mathrm{m}} \approx-60 \mathrm{kPa}\right)$ and $30 \%\left(\Psi_{\mathrm{m}} \approx-80 \mathrm{kPa}\right)$ of the water received by control plants, respectively.

One drip irrigation line was used for each row with two compensating drippers $\left(\mathrm{q}_{\mathrm{e}}=\right.$ $2 \mathrm{~L} \cdot \mathrm{h}^{-1}$ ) for each plant (Netafim; Kibbutz Hatzerim, Hanegew, Israel). The irrigation water during the experimental period had an average electrical conductivity of $1.3 \mathrm{dS} \cdot \mathrm{m}^{-1}$ for all treatments. Irrigation frequency was daily for all treatments, although differences in their duration of irrigation were imposed. The total water amount applied by irrigation throughout the experimental time was $167 \mathrm{~mm}$
Measurements of plant water status and gas exchange. Shoot water potential $\left(\Psi_{1}\right)$ was measured monthly at predawn and solar midday in three plants per plot (nine plants per treatment). Sampled shoots were enclosed in a plastic bag (Turner, 1988), which was immediately placed in a pressure chamber (Soil Moisture Equipment Co; Santa Barbara, CA) according to Scholander et al. (1965), raising the pressure at a rate of $0.03 \mathrm{MPa} \cdot \mathrm{s}^{-1}$ using nitrogen gas. The relative water content (RWC) was also measured at predawn and solar midday according to Weatherley and Barrs (1965) and calculated from the following equation:

$$
\begin{aligned}
\mathrm{RWC}= & (\text { fresh weight }- \text { dry weight }) / \\
& (\text { saturated weight }- \text { dry weight }) \times 100
\end{aligned}
$$

Stomatal conductance $\left(g_{\mathrm{S}}\right)$ was determined in the same day and at the same plants as shoot water potential using a steady-state porometer in which a sensing head was fitted with a cylindrical chamber (LI-1600-07; LI-COR, Lincoln, NE) based on measuring the flow of dry air necessary to balance the water transpired by the shoots placed in the measuring tray. Measurements were made at solar midday on attached sun-exposed shoots.

Statistical analysis. Statistical differences between treatments were analyzed by analysis of variance using SPSS (11.0; SPSS, Chicago). Differences were considered significant when $P<0.05$.

\section{Results and Discussion}

Vegetative growth. In our conditions, the deficit irrigation treatments produced changes in vegetative growth of plants of Rosmarinus officinalis, which promoted shorter plants that were more compact. Thus, shoot growth was reduced $40 \%$ to $45 \%$ with respect to control treatment from April to August. Two main periods of vegetative growth were observed in all treatments; the most important corresponded to spring and another less important in the fall (October) (Fig. 3). Terminal shoot growth was greater than lateral shoot growth in all irrigation treatments at the end of the experimental period (Table 1). Deficit irrigation had a significant effect on the plant height at the end of the experimental period (Table 2). A reduction in plant height of $43 \%$ and $50 \%$ in $\mathrm{T}-1$ and $\mathrm{T}-2$, respectively, with respect to the control was observed. However, the irrigation treatments did not promote any significant differences in ground coverage (Table 2).

This behavior has been observed in ornamental species such as Sedum dasyphyllum (Bañón et al., 2006; García and Schwarzer, 2000), which showed a good response in terms of growth and appearance when grown under limited irrigation. Growth reduction as a result of water deficit has been widely reported (de Herralde et al., 1998; SánchezBlanco et al., 2004a, 2004b; Steinberg et al., 1990). These changes can be considered as a morphological adaptation of the plant to water and environmental stresses to reduce 


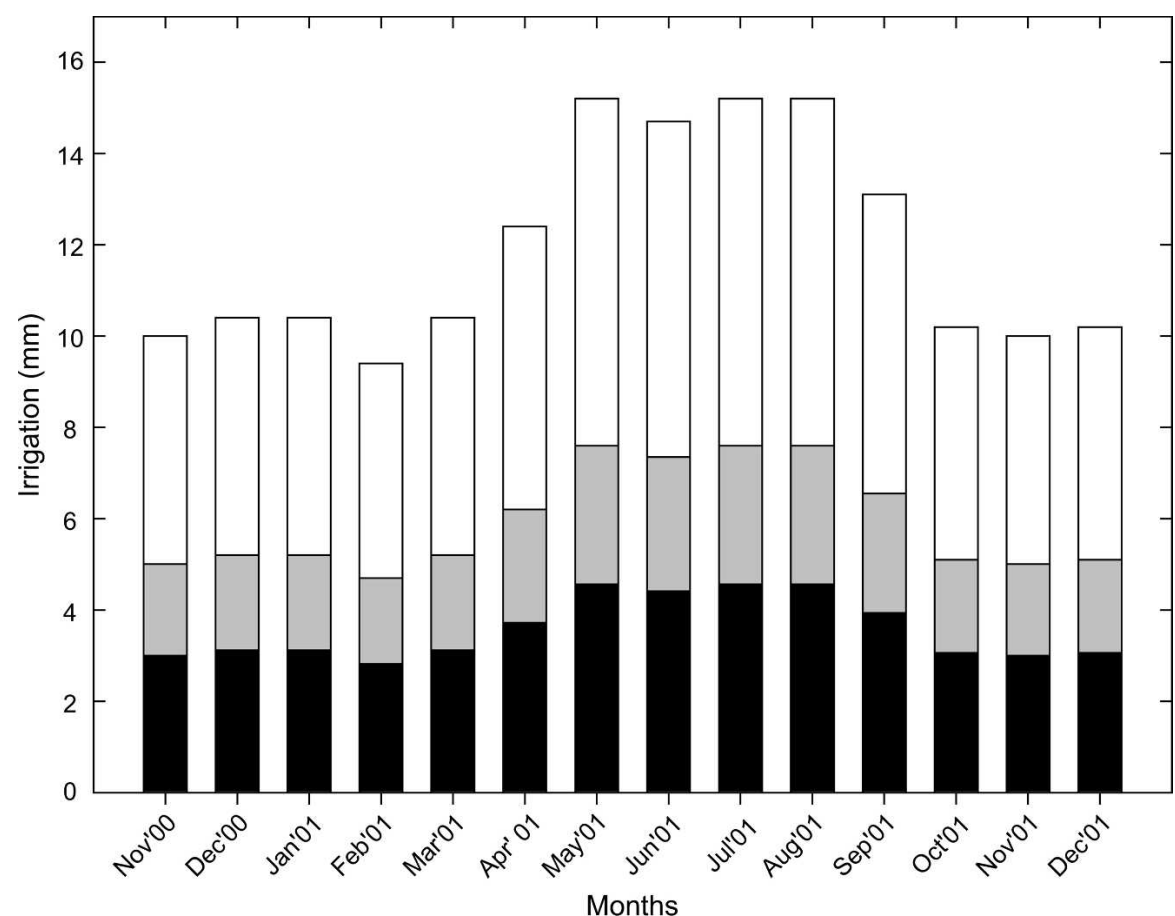

Fig. 2. Irrigation water applied $(\mathrm{mm})$ monthly in the different irrigation treatments: control (white histograms), T-1 (gray histograms), and T-2 (black histograms) plants.

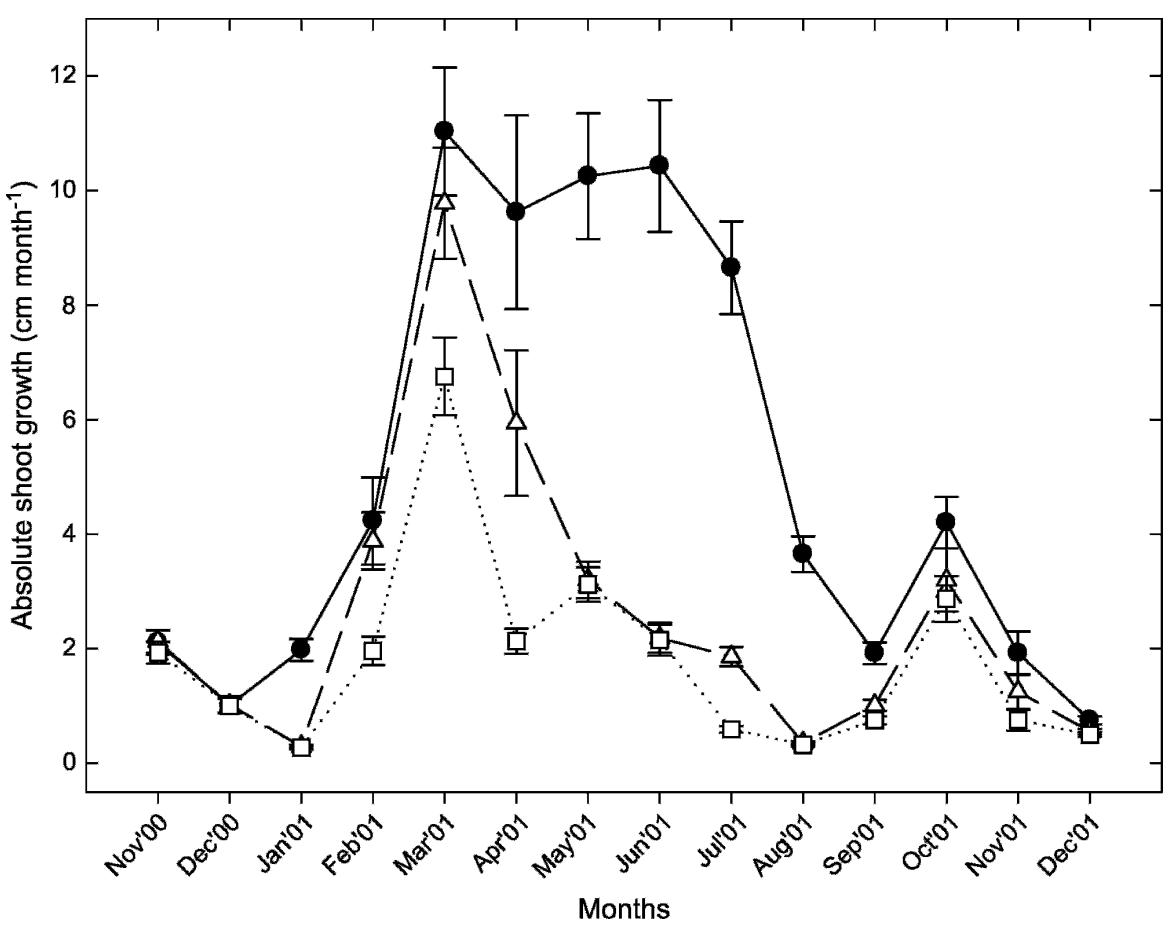

Fig. 3. Absolute shoot growth ( $\mathrm{cm} / \mathrm{month})$ for $R$. officinalis plants along the experimental period in the different irrigation treatments: control (black circles), T-1 (white triangles), and T-2 (white squares). Vertical bars are SE of the mean of 18 replicates.

transpiration and to induce a lower consumption of water (Bañón et al., 2003; Stanhill and Albers, 1974). Also, at the same time, these morphological responses may be interesting to improve the ornamental value of plants, because a reduction in plant height
Table 1. Accumulative terminal and lateral shoot growth (cm/year/shoot) for $R$. officinalis plants within the three irrigation treatments: control $(100 \%)$, T-1 $(50 \%$ of the control), and $\mathrm{T}-2$ $(30 \% \text { of the control })^{\mathrm{z}}$.

\begin{tabular}{lcc}
\hline Treatments & Terminal & Lateral \\
\hline Control & $34.63 \pm 0.71 \mathrm{a}$ & $3.11 \pm 0.08 \mathrm{a}$ \\
T-1 & $20.42 \pm 0.68 \mathrm{~b}$ & $1.24 \pm 0.06 \mathrm{~b}$ \\
T-2 & $19.75 \pm 0.62 \mathrm{~b}$ & $1.52 \pm 0.05 \mathrm{~b}$ \\
\hline
\end{tabular}

${ }^{\mathrm{z}}$ Each value represents the mean $\pm \mathrm{SE}$ of 18 values. Means within a column with different letters were significantly different by the least significant difference $_{0.05}$ test.

Table 2. Height $(\mathrm{cm})$ and ground cover $\left(\mathrm{cm}^{2}\right)$ for $R$. officinalis plants within the three irrigation treatments: control $(100 \%)$, T-1 $(50 \%$ of the control), and T-2 (30\% of the control) at the end of the experimental period ${ }^{\mathrm{z}}$.

\begin{tabular}{lcc}
\hline Treatments & Ht $(\mathrm{cm})$ & Ground cover $\left(\mathrm{cm}^{2}\right)$ \\
\hline Control & $64.83 \pm 5.06 \mathrm{a}$ & $4,198.7 \pm 333.96 \mathrm{a}$ \\
$\mathrm{T}-1$ & $37.40 \pm 2.55 \mathrm{~b}$ & $3,796.4 \pm 248.07 \mathrm{a}$
\end{tabular}

$\mathrm{T}-2 \quad 32.20 \pm 2.1 \mathrm{c} \quad 3,660.8 \pm 221.32 \mathrm{a}$

${ }^{\mathrm{z}}$ Each value represents the mean \pm SE of 18 values. Means within a column with different letters were significantly different by the least significant difference $_{0.05}$ test.

(2000) in Arbutus unedo under different irrigation conditions.

Flowering pattern. In our assay, maximum flowering intensity coincided with the beginning of fall in all treatments and a low flowering intensity was noted in summer. A higher number of flowers per surface in the T2 treatment were detected in the first months of the experiment (Nov. 2000 to Mar. 2001) (Fig. 4) and with a lower number of flowers per square meter than in natural rainfed conditions (Ferrández, 2002) (Fig. 4). T-1 treatment had a highest number of flowers per surface on Oct. 2001 (Fig. 4). However, the total number of flowers per plant was higher in the control treatment because these plants had greater growth. A more prolonged flowering process in control treatment was observed the flowering longevity ranged between 13 weeks for the control treatment and 11 weeks for the T-2 treatment.

According to numerous authors, water stress may affect the flowering process, resulting in a higher flowering intensity in ornamental plants (Morales, 1999; SánchezBlanco et al., 1998) and fruit trees (Boland et al., 1993; Dasberg et al., 1991). In our conditions, although the control plants presented a higher number of flowers per plant, at some times, the deficit irrigation treatments had more flowers per surface (Fig. 4), suggesting that the water deficit induced more intense flowering. According to Sardans et al. (2005), water addition did not increase the flowering effort of $R$. officinalis plants.

Water relations. The results concerning to the plant water status of the plants show that in control treatment, shoot water potential at predawn $\left(\Psi_{\mathrm{pd}}\right)$ was very constant during the entire experimental period (ranging from -0.4 


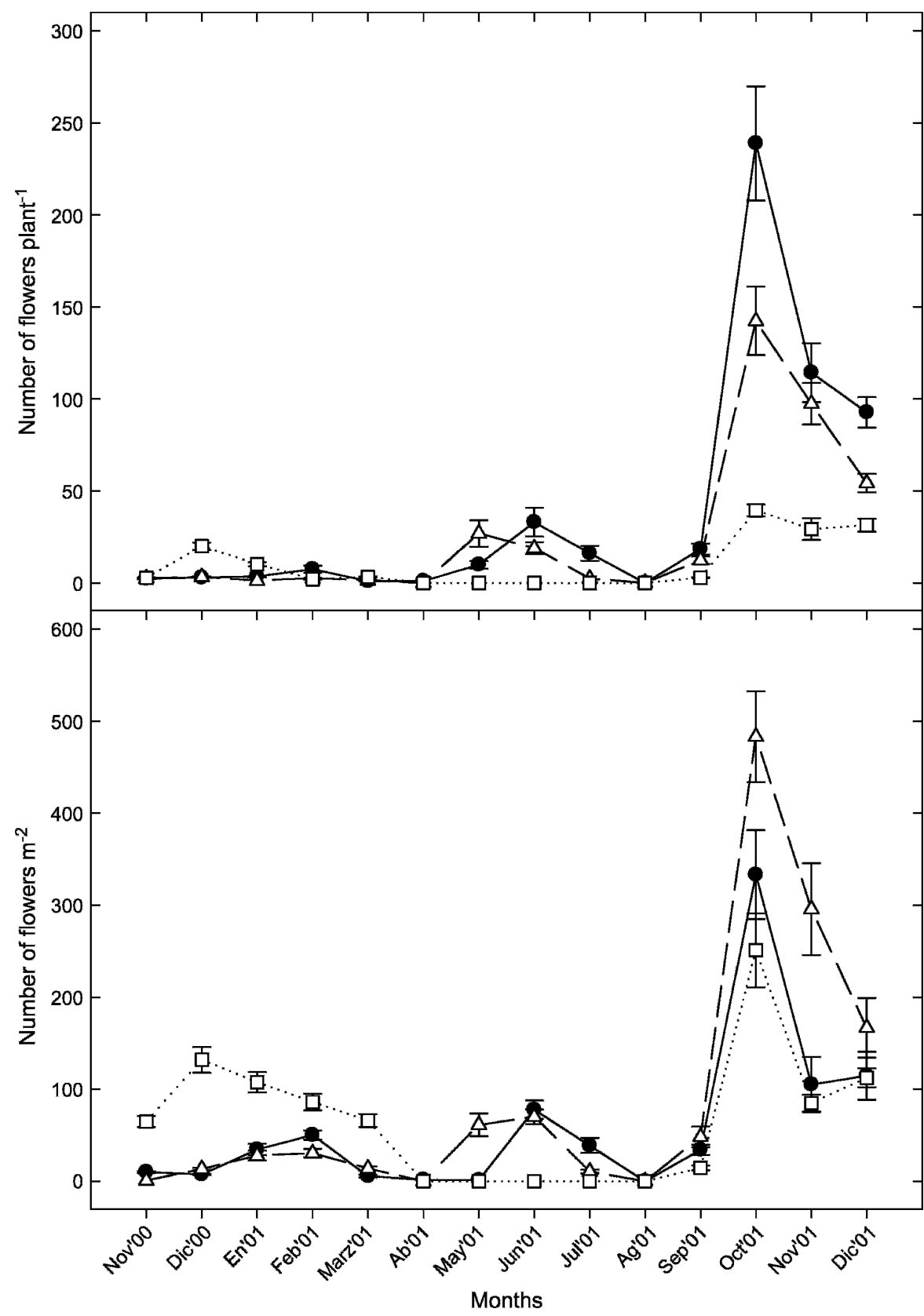

Fig. 4. Flowering intensity and longetivity within for $R$. officinalis plants along the experimental period in the different irrigation treatments: control (black circles), T-1 (white triangles), and T-2 (white squares). Vertical bars are SE of the mean of 18 replicates.

to $-0.6 \mathrm{MPa}$ ). However, deficit irrigation caused a significant decrease in $\Psi_{\mathrm{pd}}$ from March to October, reaching the minimum values in June (-1.4 MPa) (Fig. 5). These reductions were similar in both deficit irrigation treatments (T-1 and T-2). The higher $\Psi_{\text {pd }}$ values in the control treatment during the growing season show that leaf water potential at predawn reflects the availability of soil water to the plants and is a good indicator of soil moisture conditions (Aussenac and Valette, 1982; Domingo et al., 1996). Also, the constant values in this parameter during the growing season indicated that control plants were well irrigated during the entire experimental period. The values obtained in deficit-irrigated treatments coincided with those obtained by Munné-Bosch dance with the idea that leaf water potential at midday decreases when the vapor pressure deficit of the atmosphere increases (Passioura, 1982) (see Fig. 1B). At this time, climatic factors have more influence than water soil condition, and no differences by irrigation effect were observed (Fig. 5).

Similar behavior as that observed for $\Psi_{\mathrm{pd}}$ and $\Psi_{\mathrm{md}}$ was detected when the relative water content measured at predawn and midday (RWC) was considered (Fig. 5). Thus, RWC at predawn was significantly lower from April to September in the deficit treatments with respect to the control plants. However, these differences were less marked in the RWC values at midday in T-1 and T-2 plants and only significant differences with respect to the control plants were shown from April to June. These reductions were statistically similar in both deficit irrigation treatments (Fig. 5). The RWC reflects the plant water status, although the values at solar midday in all treatments were similar from July to the end of the season. This can be explained by the seasonal osmotic adjustment process that allows more changes in leaf water potential than in relative water content (Munné-Bosch et al., 1999; Sánchez-Blanco et al., 1998). The capacity of osmotic adjustment of $R$. officinalis plants under drought conditions has been reported by SánchezBlanco et al. (2004a, 2004b).

Stomatal conductance values ranged between $100 \mathrm{mmol} \cdot \mathrm{m}^{-2} \cdot \mathrm{s}^{-1}$ for the T-2 treatment to $300 \mathrm{mmol} \cdot \mathrm{m}^{-2} \cdot \mathrm{s}^{-1}$ for the control plants (Fig. 6). From March to September, the plants submitted to deficit irrigation conditions showed significantly lower values with respect to well-irrigated plants after which a recovery of $g_{\mathrm{S}}$ values was detected and no differences among treatments were observed. Rosmarinus officinalis, like many other Mediterranean perennials, shows a conservative strategy in the use of water (Munné-Bosch et al., 1998, 1999; Sánchez-Blanco et al., 2004a, 2004b) based mainly on the avoidance of drought stress by reducing the transpiration rate, that is, reducing the $g_{\mathrm{S}}$, as was observed in water-stressed conditions (Fig. 6).

\section{Conclusions}

et al. (1999) in water-stressed $R$. officinalis plants.

Seasonal patterns of shoot potential at solar midday $\left(\Psi_{\mathrm{md}}\right)$ showed a similar pattern of $\Psi_{\mathrm{pd}}$, although the differences between control and deficit treatments were less important. A significantly marked decrease was noted in $\Psi_{\text {md }}$ values from April to August in water deficit treatments, after which $\Psi_{\text {md }}$ values progressively increased and were similar to the control plants (Fig. 5). The fact that in our assay, the differences among control and deficit treatments were greater for $\Psi_{\mathrm{pd}}$ than for $\Psi_{\mathrm{md}}$ is in agreement with the idea that $\Psi_{\mathrm{pd}}$ is a more useful indicator of plant water status. In the fall and winter seasons, $\Psi_{\text {md }}$ values were high in the three treatments. This fact is in accor-
The responses of $R$. officinalis plant in terms of growth, water status, and flowering characteristics were similar for both deficit irrigation conditions. In general, the application of deficit irrigation was seen to substantially limit growth and the morphological parameters studied. Rosmarinus officinalis plants showed reduction in plant height and shoots growth, more intense flowering, and a more efficient stomatal regulation as has been observed in other Mediterranean species (Sachs and Shaw, 1992). This finding may be of use for the successful gardening of Rosmarinus officinalis plants in semiarid conditions, which could promote considerable savings in water while maintaining the ornamental value of the plants. 


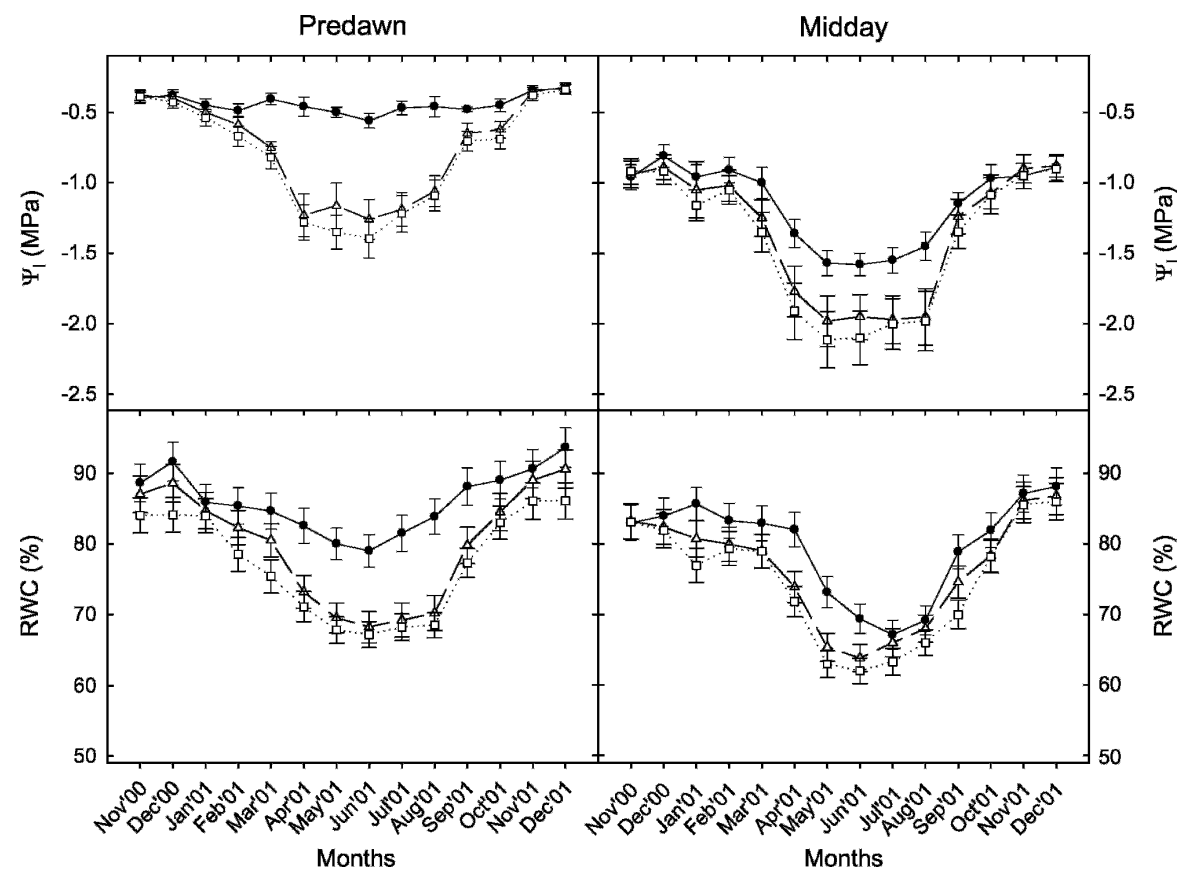

Fig. 5. Shoot water potential $\left[\Psi_{1}(\mathrm{MPa})\right]$ and relative water content $[\mathrm{RWC}(\%)]$ measured at predawn and at solar midday for $R$. officinalis plants along the experimental period in the different irrigation treatments: control (black circles), T-1 (white triangles), and T-2 (white squares). Vertical bars are SE of the mean of nine replicates.

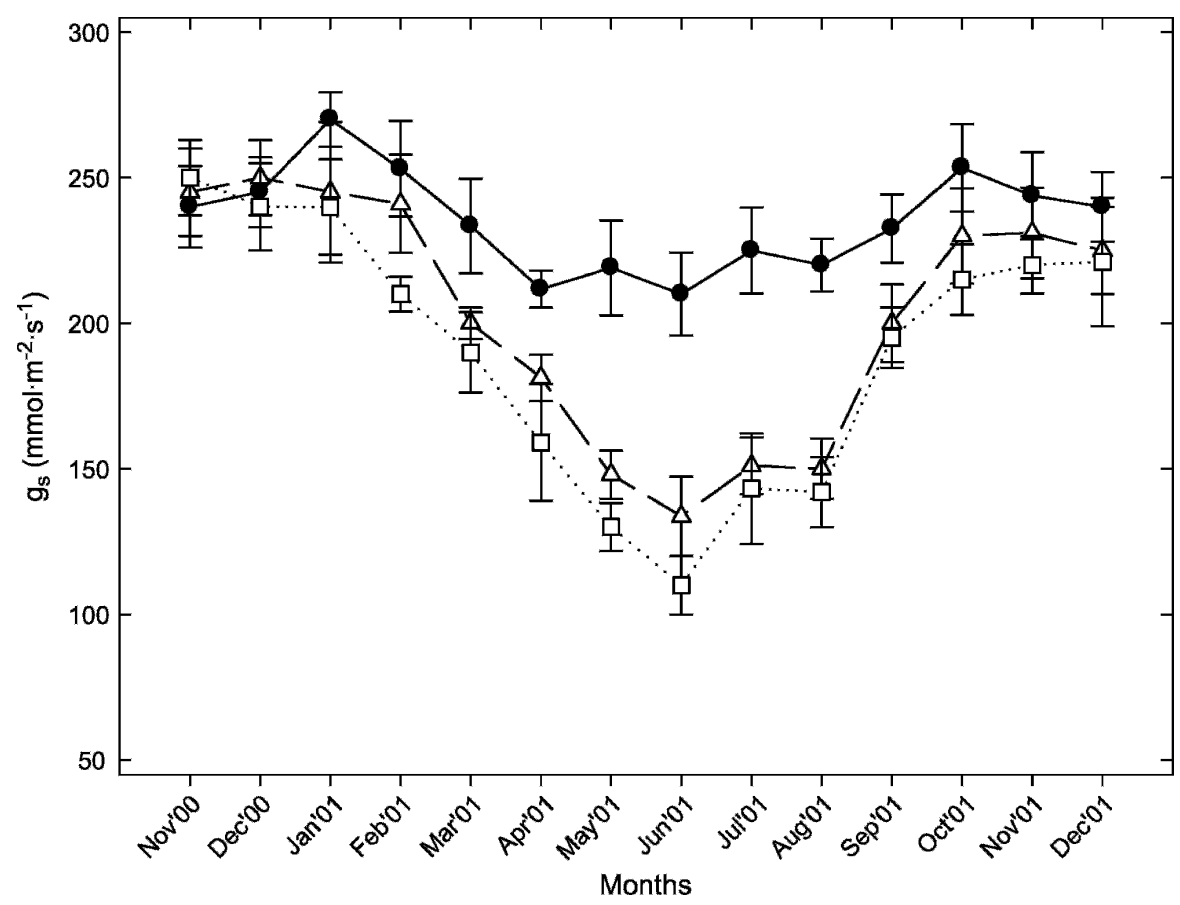

Fig. 6. Stomatal conductance $\left[g_{\mathrm{S}}\left(\mathrm{mmol} \cdot \mathrm{m}^{-2} \cdot \mathrm{s}^{-1}\right)\right]$ at solar midday for $R$. officinalis plants along the experimental period in the different irrigation treatments: control (black circles), T-1 (white triangles), and T-2 (white squares). Vertical bars are SE of the mean of nine replicates.

\section{Literature Cited}

Araújo-Alves, J.P., J.M. Torres-Pereira, C. Biel, F. de Herralde, and R. Savé. 2000. Effects of minimum irrigation technique on ornamental parameters of two Mediterranean species used in xerogardening and landscaping. Acta Hort. $541: 353-358$. riego deficitario. Proc. of the VIII Simposium Hispano-Portugués de Relaciones Hídricas en la Plantas. Tenerife-Islas Canarias, Spain. p. 122126.

Bañón, S., J. Ochoa, J.A. Franco, M.J. SánchezBlanco, and J.J. Alarcón. 2003. Influence of water deficit and low air humidity in the nursery on survival of Rhamnus alaternus seedlings following planting. J. Hort. Sci. Biotechnol. 78:518-522.

Boland, A.M., P.D. Mitchell, and P.H. Jerie. 1993. Effect of saline water combined with restricted irrigation on peach trees growth and water use. J. Agr. Res. 44:799-816.

Clary, J., R. Savé, C. Biel, and F. de Herralde. 2004. Water relations in competitive interactions of Mediterranean grasses and shrubs. Ann. Appl. Biol. 144:149-155.

Dasberg, S., H. Biolorai, A. Haimowitz, and Y. Ernar. 1991. The effect of saline water on Shamounti orange trees. Irr. Sci. 12:205-211.

de Herralde, F., C. Biel, R. Savé, M.A. Morales, A. Torrecillas, J.J. Alarcón, and M.J. SánchezBlanco. 1998. Effect of water and salt stresses on the growth, gas exchange and water relations in Argyranthemum coronopifolium plants. Plant Sci. 139:9-17.

Domingo, R., M.C. Ruiz-Sánchez, M.J. SánchezBlanco, and A. Torrecillas. 1996. Water relations, growth and yield of fino lemon trees under regulated deficit irrigation. Irrig. Sci. 16: $115-123$.

Ferrández, T. 2002. Estudio ecofisiológico del Romero (Rosmarinus officinalis L.) en ambientes semiáridos: Aplicaciones agronómicas y paisajísticas. University of Murcia, Murcia, Spain. Thesis.

Franco, J.A., S. Bañón, J.A. Fernández, and D.I. Leskovar. 2000. Effect of nursery regimes and establishment on root development of Lotus creticus seedlings following transplanting. J. Hort. Sci. Biotechnol. 76:174-179.

Franco, J.A., J.J. Martínez-Sánchez, J.A. Fernández, and S. Bañón. 2006. Selection and nursery production of ornamental plants for lanscaping and xerogardening in semi-arid environments. J. Hort. Sci. Biotechnol. 81:3-17.

García, M.L. and H. Schwarzer. 2000. Producción en contenedores de dos especies silvestres del género Sedum bajo distintas dosis de riego. Actas de las IV Jornadas de Grupo de Ornamentales de la S.E.C.H. Cartagena-Murcia, Spain.

Han, S. and K. Kim. 1999. Effects of growth retardans on growth, flowering, and germination of harvested seed in Clinopodium chinense var. parviflorum. J. Korean Soc. Hort. Sci. 40:765-768.

Ludlow, M.M. 1989. Strategies of response to water stress, p. 268-281. In: Kreeb, K.H. H. Ritcher, and T.M. Hinckley (eds.). Structural and functional responses to environmental stresses. SPB Academic Publishing, The Hague, The Netherlands.

Morales, M.A. 1999. Aspectos agronómicos y fisiológicos de la respuesta a la salinidad de plantas ornamentales silvestres (Limonium sp., Lotus creticus creticus y Argyranthemum coronopifolium). University of Murcia, Murcia, Spain. Thesis.

Morales, M.A., M.J. Sánchez-Blanco, E. Olmos, A. Torrecillas, and J.J. Alarcón. 1998. Changes in the growth, leaf water relations and cell ultrastructure in Argyranthemum coronopifolium plants under saline conditions. J. Plant Physiol. 153:174-180.

Munné-Bosch, S., S. Nogués, and L. Alegre. 1998. Daily patterns of photosynthesis of two 
Mediterranean Schrubs response to water deficit, p. 4015-4018. In: Garab, G. (ed.). Photosynthesis: Mechanisms and effects. Kluwer Academic Publishers, Dordrecht, The Netherlands.

Munné-Bosch, S., S. Nogués, and L. Alegre. 1999. Diurnal variations of photosynthesis and dew absorption by leaves in two evergreen shrubs growing in Mediterranean field conditions. New Phytol. 144:109-119.

Passioura, J.B. 1982. Water in the soil-plantatmosphere continuum, p. 5-33. In: Lange, O.L., P.S. Nobel, C.B. Osmond, and H. Zeiegler (eds.). Physiological plant ecology. II. Water relation and carbon assimilation. Encyclopedia of plant physiology, new series. Vol. 12B. Springer-Verlag, Berlin, Germany.

Primack, R.B. 1985. Longevity of individual flowers. Annu. Rev. Ecol. Syst. 16:15-38.

Sachs, R.M. and D.A. Shaw. 1992. Minimum irrigation requires acclimatized (hardened) plants. J. Arboric. 21:126-131.

Sánchez-Blanco, M.J., T. Ferrández, M.A. Morales, A. Morte, and J.J. Alarcón. 2004a. Variations in water status, gas exchange, and growth in Rosmarinus officinalis plants infected with Glomus deserticola under drought conditions. J. Plant Physiol. 161:675-682.

Sánchez-Blanco, M.J., T. Ferrández, A. Navarro, S. Bañón, and J.J. Alarcón. 2004b. Effects of irrigation and air humidity preconditioning on water relations, growth and survival of Rosmarinus officinalis plant during and after transplanting. J. Plant Physiol. 161:1133-1142.

Sánchez-Blanco, M.J., M.A. Morales, A. Torrecillas, and J.J. Alarcón. 1998. Diurnal and seasonal osmotic potential changes in Lotus creticus creticus plants grown under saline stress. Plant Sci. 136:1-10

Sardans, J., F. Rodá, and J. Peñuelas. 2005. Effects of water and nutrient pulse supply on Rosmarinus officinalis growth, nutrient content and flowering in the field. Environ. Exp. Bot. 53:1-11.

Savé, R., L. Alegre, M. Pery, and J. Terradas. 1993. Ecophysiology after fire resprouts of Arbutus unedo L. ORSIS 8:107-119.

Savé, R., C. Castell, and J. Terradas. 1999. Gas exchange and water relations, p. 135-147. In: Rodà, F. (ed.). Ecology of Mediterranean evergreen oak forests. Springer-Verlag, Berlin, Germany.
Scholander, P.F., H.T. Hammel, E.D. Bradstreet, and E.A. Hemmingsen. 1965. Sap pressure in vascular plants. Science 148:339-346.

Silva, C.P. and J.F. Pedras. 1999. Early rooting in rosemary's (Rosmarinus officinalis) cuttings under the influence of chemical treatments and collecting time. Acta Hort. 502:213-217.

Singh, D.B., M. Sunjoy, N.C. Bensam, and S. Mehra. 1999. Effect of paclobutrazol on flowering of chrysanthemum. J. Ornam. Hort. Sci. 36:98-106.

Stanhill, G. and J.S. Albers. 1974. Solar radiation and water loss from greenhouse roses. J. Amer. Soc. Hort. Sci. 99:107-110.

Steinberg, S.L., J.C. Miller, and M.J. Mcfarland. 1990. Dry matter partitioning and vegetative growth of young peach trees under water stress. Aust. J. Plant Physiol. 17:23-36.

Turner, N.C. 1988. Measurement of plant water status by the pressure chamber technique. Irrig. Sci. 9:289-308.

Weatherley, P.E. and C. Barrs. 1965. An examination of the relative turgidity technique for estimating water deficit in leaves. Aust. J. Plant Physiol. 15:413-428. 